\title{
Wushu Sanda: Color bias, home advantage and motor actions analysis in female matches' from the 13th World Championships
}

\author{
Breno Berny VASCONCELOS* \& Fabrício Boscolo DEL VECCHIO \\ Physical Education College, Federal University of Pelotas, Pelotas, Rio Grande do Sul (Brazil)
}

Recepción: 03/03/2017; Aceptación: 25/05/2017; Publicación: 27/05/2017.

\begin{abstract}
Introduction: Wushu Sanda is a mixed orientation combat sport in which athletes duel wearing red or black clothes. Despite its popularity, the knowledge about its technical and psychophysiological aspects are scarce. Objective: The aim of this study was to quantify the motor actions and the color bias and home advantage existence possibility in female matches from the $13^{\text {th }}$ World Wushu Championships, held in Indonesia, 2015. Material and methods: In an observational study were analyzed 46 matches involving 55 athletes. Each match was analyzed twice, and were considered 22 possible techniques ( 5 types of punches, 5 types of kicks and 12 different throws). All the motor actions were registered for each athlete, aside of match outcome, clothing color and continent of origin. Results: From all applied motor actions, 48.2\% were punches, $46.9 \%$ were kicks and $4.8 \%$ were throws. Athletes applied $11 \pm 8.67$ punches, $10.7 \pm 5.63$ kicks and $1.1 \pm 1.6$ throws per round. The number of throwing techniques applied on the first and second rounds was higher in winners ( $\mathrm{F}=10.24, p=0.002$ and $\mathrm{F}=7.82, p=0.006$ respectively). No differences were found in motor behavior among distinct competitive phases $\left(\mathrm{F}(3 ; 88)=1.87 ; p=0.140 ; \eta^{2} \mathrm{p}=0.06\right)$. Home advantage was observed supporting Asian athletes $\left(\chi^{2}=10.12, p=0.038\right)$. Color bias was observed supporting athletes who wore red $\left(\chi^{2}=8.52, p=0.004\right)$, which won a higher number of matches (65\%). Conclusions: To the detriment of grappling actions (throws), female international level Wushu Sanda athletes predominantly used striking motor actions (punches and kicks). Winners applied a higher number of throws than losers. Home advantage was observed supporting Asian athletes. Color bias was observed supporting female athletes who wore red.
\end{abstract}

Keywords: Wushu Sanda; time-motion analysis; color bias; home advantage; martial arts; combat sports.

\section{Wushu Sanda: sesgo de color, ventaja local y análisis de acciones motrices en combates femeninos de los $13^{\text {os }}$ Campeonatos Mundiales Resumen}

Introducción: El Wushu Sanda es un deporte de combate de orientación mixta en el que los atletas compiten con uniformes de color rojo o negro. A pesar de su popularidad, el conocimiento sobre sus aspectos técnicos y psicofisiológicos es escaso. Objetivo: El objetivo de este estudio fue cuantificar las acciones motrices y la posibilidad de que existiese sesgo de color o ventajas por condición de local en combates femeninos de los $13^{\text {os }}$ Campeonatos Mundiales de Wushu, celebrados en Indonesia en 2015. Material y métodos: En un estudio observacional se analizaron 46 combates realizados por 55 atletas. Cada combate fue analizado dos veces, y se consideraron 22 posibles técnicas ( 5 tipos de golpes de puño, 5 tipos de patadas y 12 proyecciones). Todas las acciones motrices fueron registradas para cada atleta, independientemente del resultado del combate, del color del uniforme y del continente de origen. Resultados: De todas las acciones motrices aplicadas, el $48,2 \%$ fueron golpes de puño, el $46,9 \%$ fueron patadas y el $4,8 \%$ fueron proyecciones. Los atletas aplicaron $11 \pm 8,67$ golpes de puño, $10,7 \pm 5,63$ patadas $\mathrm{y}$ $1,1 \pm 1,6$ proyecciones por asalto. El número de técnicas de proyección aplicadas en el primer y segundo asalto fue mayor en los ganadores $(\mathrm{F}=10,24, p=0,002$ y $\mathrm{F}=7,82$, $p=0,006$, respectivamente). No se encontraron diferencias en
Wushu Sanda: Viés de cores, home advantage e análise de ações motoras em lutas femininas do $13^{\circ}$ campeonato mundial

\section{Resumo}

Introdução: Wushu Sanda é uma modalidade esportiva de combate de orientação mista na qual os atletas lutam vestindo uniforme vermelho ou preto. Apesar da popularidade crescente, conhecimentos sobre aspectos técnicos e psicofisiológicos da modalidade são escassos. Objetivo: 0 objetivo deste estudo foi quantificar a utilização de ações motoras e investigar a possibilidade de existência de viés de cores e home advantage em lutas femininas do $13^{\text {o }}$ Campeonato Mundial de Wushu, realizado na Indonésia, 2015. Materiais e métodos: Em um delineamento observacional foram analisadas 46 lutas envolvendo 55 atletas. Cada luta foi analisada duas vezes e foram considerados 22 tipos de ações motoras ( 5 tipos de socos, 5 tipos de chutes e 12 técnicas de projeção). Todas as ações motoras realizadas por cada atleta foram registradas, além do desfecho da luta, cor do uniforme e continente de origem. Resultados: De todas as ações motoras aplicadas, 48,2\% foram socos, $46,9 \%$ foram chutes e $4,8 \%$ foram projeções. As atletas aplicaram $11 \pm 8,67$ socos, $10,7 \pm 5,63$ chutes e 1,1 11,6 projeções por round. Vencedoras aplicaram maior número de projeções no primeiro e no segundo round ( $\mathrm{F}=10,24, p=0,002$ e $\mathrm{F}=7,82, p=0,006$ respectivamente). Nenhuma mudança foi observada no comportamento 
el comportamiento motor entre fases competitivas distintas $\left(\mathrm{F}(3 ; 88)=1.87 ; p=0.140 ; \eta^{2} \mathrm{p}=0.06\right)$. Se observó una ventaja por condición de local que apoyaba a los atletas asiáticos $\left(\chi^{2}=10.12, p=0.038\right)$. Se observó sesgo de color a favor de las atletas que llevaban rojo $(\chi 2=8.52, p=0.004)$, las cuales ganaron un mayor número de combates (65\%). Conclusiones: En detrimento de las acciones de lucha (proyecciones), las atletas femeninas de nivel internacional de Wushu Sanda utilizaron fundamentalmente acciones motrices basadas en el impacto (golpes de puño y patadas). Las ganadoras aplicaron un mayor número de proyecciones que las perdedoras. Se observó ventaja por condición de local a favor de las atletas asiáticas. Se observó sesgo de color a favor de las competidoras que llevaban uniforme rojo.

Palabras clave: Wushu Sanda; análisis de tiempomovimiento; sesgo de color; ventaja local; artes marciales; deportes de combate. motor em diferentes fases competitivas $(F(3 ; 88)=1,87$; $\left.p=0,140 ; \eta^{2} \mathrm{p}=0,06\right)$. Foi observado home advantage favorecendo atletas asiáticas $\left(\chi^{2}=10,12, p=0,038\right)$. Foi observado viés de cor favorecendo atletas que lutaram vestindo vermelho $\left(\chi^{2}=8.52, p=0,004\right)$, as quais venceram um número maior de combates (65\%). Conclusões: Atletas femininas de Wushu Sanda de nível internacional utilizam predominantemente ações motoras de percussão (socos e chutes) em detrimento a ações motoras de domínio (projeções). Vencedoras aplicam maior número de projeções que perdedoras. Home advantage foi observado, favorecendo atletas da Ásia. Viés de cor foi observado, favorecendo atletas que vestem vermelho.

Palavras-chave: Wushu sanda; análise de tempomovimento; viés de cor; home advantage; artes marciais; desportos de combate.

\section{Introduction}

Sanda is a combat sport (CS) developed from Wushu - frequently named Kung-Fu - which involves striking actions, such as punches and kicks, and grappling actions, such as throwing (Zeng, Zhang, \& Zhou, 2009). Although its popularity growth due to the efforts for bringing Wushu to the Olympic Games (IWUF, 2014), few studies has explored its technical-tactical aspects (Yin, 2010; Chang, 2013) and its motor, physiological and perceptive implications (Li \& Qiu, 2012; Liu \& Zhang, 2007). Understanding the technical-tactical patterns and physiological and perceptive effects linked to the CS is relevant for training optimization, which can improve athletes' competitive performance (Franchini \& Del Vecchio, 2011).

Previous studies analyzing technical and tactical patterns in CS showed that each modality has specific characteristics and evidenced determinant factors to victory. In Taekwondo, winning male competitors tend to gain more points in second and third rounds and apply more counterattacks (Kazemi, Perri, \& Soave, 2006). On Judo, mastering more than ten throwing techniques and applying them in three different directions is considered as a determinant factor to victory among high-level athletes (Franchini \& Del Vecchio, 2010). However, on Sanda, studies about this subject are scarce (Jiang, Olson \& Li, 2013; Artioli et al., 2009). A previous investigation, performed among Chinese athletes, indicated that female competitors tend to use fewer throwing techniques, focusing their repertory on punches and kicks (Chang, 2013). This technical-tactical profile differs to that observed in male competitors, who during 2009's Chinese National Championship tended to rely more on throwing techniques (Yin, 2010).

Beyond technical-tactical patterns, there are psychophysiological aspects which exceed the fighters' physical fitness and contribute in winner's definition, such as the home advantage (Julio, Panissa, Miarka \& Franchini, 2013) the color bias (Dreiskaemper, Strauss, Hagemann \& Büsch, 2013). Home advantage may be defined as the advantage that athletes have by competing at home when compared with their performance abroad (Julio et al., 2012). A previous study pointed its existence in CS from the Olympic Games, such as Taekwondo, Boxing, Wrestling and Fencing, which affected the number of medals and quantity of wins (Franchini \& Takito, 2016). Color bias may be defined as the advantage that athletes have by competing wearing clothes with certain colors (Dreiskaemper et al., 2013). On Judo, CS in which competitors wear blue or white, studies indicated that athletes wearing blue seem to have an advantage (Julio et al., 2015; Rowe, Harris \& Roberts, 2005). Hill and Barton (2005) showed that athletes wearing red have a high number of victory when compared to those wearing blue in CS from the Olympic Games (Wrestling, Taekwondo and Boxing). Despite of having no consensus about this kind of bias, psychological and perceptive responses are most used to explain it (Rowe et al., 2005). In this sense, Sanda is unique, since athletes wear red or black clothes, being different from all cited CS.

Although the competitive scene is still unequal between genders, with less Olympic modalities for women, female athletes are gaining their place on CS (Pasque, 2009; Miarka, 
Marques, \& Franchini, 2011), what makes specific studies about this public necessary (Miarka et al., 2011), specially for a better understanding of the competitive dynamics. Besides, there are few studies investigating motor actions and no one investigating color bias and home advantage existence possibility on Wushu Sanda. Therefore, the aim of this study is to describe the motor actions, comparing them by weight category, match outcome and competitive phase, and investigate the colobias and home advantage existence in female Wushu Sanda matches from the 2015's world championship.

\section{Materials and Methods}

\subsection{Study design, population and sample}

This study has an observational cross-sectional design and its population was composed by 55 female Wushu Sanda athletes which competed at the $13^{\text {th }}$ World Wushu Championships, held in Indonesia on November 2015. The sample was composed by all female matches from the event (46 from 191, in which athletes wearing red or black were paired).

\subsection{Match analysis}

In order to guarantee ecological validity with low cost and facility to acquire the performance from international level female athletes, the combats were recorded from an online platform WushuTV (http://worldwushu.tv). All matches were streamed in high resolution and stored in a personal computer. As previously pointed (Miarka, Branco, Del Vecchio, Camey \& Franchini, 2015), the present study ensured anonymity and confidentiality by replacing the athletes' personal identification, there are no ethical issues in analyzing or interpreting data obtained at public events. After that, they were organized in female's seven weight categories, which are $-48 \mathrm{~kg},-52 \mathrm{~kg},-56 \mathrm{~kg},-60 \mathrm{~kg},-65 \mathrm{~kg},-70 \mathrm{~kg}$ e $-75 \mathrm{~kg}$.

The software Kinovea ${ }^{\mathrm{TM}}$ was utilized to the matches' analysis. For that, they were reproduced on slow motion (50\% of normal velocity), as previously reported (Silva, Del Vecchio, Picanço, Takito \& Franchini, 2011). Each match was analyzed twice, once for each athlete, so that could be possible to observe every motor action separately, and the variables of interest were registered in two tables, one for each athlete. Each table had identification (weight category, athlete's name, country, continent, number of the fight and competitive phase) and space for registering the realized motor actions (Del Vecchio, Hirata \& Franchini, 2011).

Since matches were analyzed by just one observer, the intra-rater reproducibility was evaluated in order to ensure the analysis' method reliability. For that, ten randomly selected fights were reanalyzed on a double-blind design. The reproducibility classification was excellent for all the variables, with intraclass correlation coefficients lasting between 0.75 and 0.99 . In order to analyze the fights, the following motor actions were considered, according to the European Wushu Federation (EWUF) graduation system:

1. Punches: zuǒ chōng quán (jab punch), yòu chōng quán (direct punch), guàn quán (hook punch), chāo quán (upper punch) and zhuănshēn biān quán (turning back fist strike).

2. Kicks: dēngtuǐ (front kick), cè chuài tuǐ (side kick), héng băi tī tuǐ (round kick), zhuănshēn hòu dēngtuǐ (turning back kick) and zhèng tī tuǐ (hammer kick).

3. Throws: bào tul̆ qián dǐng shuāi (foward takedown), bào tuǐ shuāi (leg-hold throw), bào tuĭ dă tuĭ shuāi (leg sweep throw), bào tuĭ shǒu bié shuāi (takedown with hand control), xià cè shăn bào yāo shuāi (side dodge waist-hold takedown), zhuănshēn cè shuāi (turning side throw), zhuănshēn luò shuāi (falling spinning throw), bào tuǐ cè shuāi (side holding leg throw), bào tuĭguò xiōng cè shuāi (leg holding side throw), jiē tuǐ cè shuāi (chatching-leg side throw), chā bào dă shuāi (cross-hold hip throw) and Undefined Throw (when the applied technique wasn't one of the before specified).

Punches and kicks were considered as striking actions and throws were considered as grappling actions. Punches and kicks were classified as applied, when they hit the opponent, or 
feint, when they did not hit the opponent. Throws were classified as 2 points, when the athlete who applied the throwing remained standing, and 1 point, when the athlete who applied the throwing fell with the opponent.

For color bias, the match outcome (victory or defeat) and the clothing color (red or black) were considered. The athletes clothing was made by a shirt, shorts, a helmet, gloves and chest protector, all in red or black dominant color, randomly determined. For home advantage investigation, the match outcome and the athlete's continent of origin (America: $n=6$; Africa: $n=5$; Asia: $n=30$; Europe: $n=13$; or Oceania: $n=1$ ) were considered.

\subsection{Statistical Analysis}

After normality test (Shapiro-Wilk), descriptive statistics were applied to quantify the means and standard deviations according to each Round, which were divided in Minute 1, Minute 2 and Round's Total. In order to compare moments, outcomes, clothing color and competitive phase, the analysis of variance (ANOVA) with repeated measures was employed. Tukey's and Boferroni's post-hoc tests were employed when properly.

For color bias investigations, clothing color was considered as an independent variable and match outcome a dependent variable. For home advantage investigation, continent of origin was considered an independent variable and match outcome a dependent variable. For both, the Chisquare test was employed. All analysis were conducted with software $I B M^{\circledR}$ SPSS ${ }^{\circledR}$ Statistics, version 20.0 .

\section{Results}

Table 1 shows the motor actions' execution numbers along the rounds. It was identified that female athletes used predominantly striking techniques $(11 \pm 8.67$ punches and $10.7 \pm 5.63$ kicks per round, respectively $48.2 \%$ and $46.9 \%$ of total motor actions), applying few throwing techniques (1.1 \pm 1.6 throws per round, $4.8 \%$ of total motor actions).

Table 1. Motor actions occurrence by round on female Wushu Sanda fights $(N=46)$

\begin{tabular}{|c|c|c|c|c|c|c|c|c|c|c|c|c|}
\hline & \multicolumn{2}{|c|}{ Punches } & \multicolumn{2}{|c|}{ Kicks } & \multicolumn{2}{|c|}{ Throws } & \multicolumn{2}{|c|}{ Strike } & \multicolumn{2}{|c|}{ Grappling } & \multicolumn{2}{|c|}{ Total } \\
\hline & $\mathbf{M}$ & $\pm S D$ & $\mathbf{M}$ & $\pm \mathrm{SD}$ & $\mathbf{M}$ & \pm SD & $\mathbf{M}$ & \pm SD & $\mathbf{M}$ & $\pm S D^{\circ}$ & $\mathbf{M}$ & $\pm \mathrm{SD}$ \\
\hline \multicolumn{13}{|l|}{ ROUND 1} \\
\hline Minute 1 & 5.5 & \pm 4.6 & 5.8 & \pm 3.3 & 0.6 & \pm 1.0 & 11.3 & \pm 5.7 & 0.6 & \pm 1.0 & 13.0 & \pm 5.8 \\
\hline Minute 2 & 4.8 & \pm 3.9 & 5.3 & \pm 3.3 & 0.6 & \pm 1.0 & 10.0 & \pm 5.4 & 0.6 & \pm 1.0 & 11.3 & \pm 5.8 \\
\hline Total & 10.3 & \pm 7.2 & 11.1 & \pm 5.7 & 1.3 & \pm 1.7 & 21.34 & \pm 9.3 & 1.3 & \pm 1.7 & 24.3 & \pm 9.7 \\
\hline \multicolumn{13}{|l|}{ ROUND 2} \\
\hline Minute 1 & 5.8 & \pm 4.6 & 5.5 & \pm 3.2 & 0.5 & \pm 0.9 & 11.3 & \pm 5.9 & 0.5 & \pm 0.9 & 12.9 & \pm 6.5 \\
\hline Minute 2 & 5.9 & \pm 7.2 & 4.8 & \pm 3.3 & 0.5 & \pm 0.9 & 10.7 & \pm 8.3 & 0.5 & \pm 0.9 & 12.1 & \pm 8.6 \\
\hline Total & 11.8 & \pm 10.1 & 10.3 & \pm 5.7 & 1.0 & \pm 1.6 & 22 & \pm 12.1 & 1.0 & \pm 1.6 & 24.9 & \pm 12.8 \\
\hline \multicolumn{13}{|l|}{ ROUND 3} \\
\hline Minute 1 & 4.1 & \pm 1.9 & 5.5 & \pm 2.0 & 0.4 & \pm 0.5 & 9.6 & \pm 2.9 & 0.4 & \pm 0.5 & 10.1 & \pm 2.5 \\
\hline Minute 2 & 5.9 & \pm 2.5 & 6.4 & \pm 3.2 & 0.6 & \pm 0.9 & 12.3 & \pm 4.2 & 0.6 & \pm 0.9 & 13.4 & \pm 4.2 \\
\hline Total & 10.0 & \pm 4.0 & 11.9 & \pm 3.8 & 1.0 & \pm 1.1 & 21.9 & \pm 6.0 & 1.0 & \pm 1.1 & 23.5 & \pm 5.1 \\
\hline
\end{tabular}

Table 2 displays the proportions of punches and kicks utilization. The hook punch was the most applied punch (38.6\% of all punches), followed by the direct punch (32\%) and the jab punch (24.2\%). Other types of punches were less used (5.1\%). Among kicking techniques, the round kick was the most applied (75.8\% of all kicks), followed by the side kick (13.1\%) and the front kick $(10.4 \%)$. Other types of kicks were very uncommonly used (.7\%).

Table 3 displays the utilization of throwing techniques. Most of them were 1 point throws (67.4\% of all throws). Athletes applied more undefined throws (35.9\% of all throws), followed by cross-hip hold throw (28.2\%), takedown with hand control and falling spinning throw (both with $16 \%)$. 
Table 2. Utilization of striking motor actions (punches and kicks; N=46)

\begin{tabular}{lccccc}
\hline \multicolumn{1}{c}{ Strinking techniques } & Applied & Feints & Total & Mean by match & \% of utilization \\
\hline PUNCHES & & & & & \\
guàn quán (hook punch) & 549 & 32 & 581 & 6.31 & $38.6 \%$ \\
yòu chōng quán (direct punch) & 468 & 14 & 482 & 5.24 & $32.0 \%$ \\
zuǒ chōng quán (jab punch) & 305 & 59 & 364 & 3.96 & $24.2 \%$ \\
Other punches & 76 & 1 & 77 & 0.84 & $5.1 \%$ \\
Total & 1398 & 106 & 1504 & & $100 \%$ \\
\hline KICKS & & & & & \\
héng băi tī tuĭ (round kick) & 981 & 145 & 1126 & 12.24 & $75.8 \%$ \\
cè chuài tuĭ (side kick) & 169 & 26 & 195 & 2.12 & $13.1 \%$ \\
Dēngtuǐ (front kick) & 131 & 23 & 154 & 1.67 & $10.4 \%$ \\
Other kicks & 10 & 1 & 11 & 0.12 & $0.7 \%$ \\
Total & 1291 & 195 & 1486 & & $100 \%$ \\
\hline
\end{tabular}

Table 3. Utilization of grappling motor actions (throwing techniques) (N=46)

\begin{tabular}{|c|c|c|c|c|c|}
\hline Throwing technique & $\begin{array}{l}\text { No. } 2 \text { points } \\
\text { throws }\end{array}$ & $\begin{array}{l}\text { No. } 1 \text { point } \\
\text { throws }\end{array}$ & Total & $\begin{array}{l}\text { Mean by } \\
\text { match }\end{array}$ & $\begin{array}{c}\% \text { of } \\
\text { utilization }\end{array}$ \\
\hline Undefined throw & 21 & 26 & 47 & 0.51 & $35.9 \%$ \\
\hline chā bào dă shuāi (cross-hold hip throw) & 3 & 34 & 37 & 0.40 & $28.2 \%$ \\
\hline $\begin{array}{l}\text { bào tuĭ shŏu bié shuãi (takedown with hand } \\
\text { control) }\end{array}$ & 10 & 11 & 21 & 0.23 & $16.0 \%$ \\
\hline $\begin{array}{c}\text { zhuănshēen luò shuāi (falling spinning } \\
\text { throw) }\end{array}$ & 0 & 21 & 21 & 0.23 & $16.0 \%$ \\
\hline bào tuĭ qián dǐng shuāi (foward takedown) & 3 & 12 & 15 & 0.16 & $8.4 \%$ \\
\hline zhuănshēn cè shuāi (turning side throw) & 12 & 2 & 14 & 0.15 & $7.9 \%$ \\
\hline bào tuĭ shuāi (leg-hold throw) & 5 & 8 & 13 & 0.14 & $7.3 \%$ \\
\hline Other throws & 4 & 6 & 10 & 0.11 & $5.6 \%$ \\
\hline Total & 58 & 120 & 131 & & $100 \%$ \\
\hline
\end{tabular}

Relating to match outcome, winners applied more throwing techniques on round 1 $\left(\mathrm{F}(1 ; 83)=10.24 ; p=0.002 ; \eta^{2} \mathrm{p}=0.110\right)$, when winners applied $2 \pm 1.93(\mathrm{CI} 95 \%=1.61 ; 2.48)$ throwing techniques while losers applied $0.5 \pm 0.86(\mathrm{CI} 95 \%=0.04 ; 0.92)$, and round $2(\mathrm{~F}(1 ; 83)=7.82 ; p=$ $\left.0.006 ; \eta^{2}=0.86\right)$, when winners applied $1.8 \pm 1.84(\mathrm{CI} 95 \%=1.46 ; 2.24)$ throws and losers applied $0.2 \pm 0.47$ (CI95\% $=-0.18 ; 0.61)$ techniques. For punches $\left(\mathrm{F}(1 ; 90)=0.347 ; p=0.557 ; \eta^{2} \mathrm{p}=0.004\right)$ and kicks $\left(\mathrm{F}(1 ; 90)=2.92 ; p=0.091 ; \eta^{2} \mathrm{p}=0.031\right)$, there are no differences due to match outcome. No differences were shown in the number of applied techniques when compared by competitive phase $\left(\mathrm{F}(3 ; 88)=1.87 ; p=0.140 ; \eta^{2}{ }_{\mathrm{p}}=0.06\right)$ and color clothing $\left(\mathrm{F}(1 ; 90)=0.06 ; p=0.806 ; \eta^{2}{ }_{\mathrm{p}}=0.001\right)$.

Analyzing the proportions of victories and defeats by color clothing, it was noticed that athletes who wore red clothes won significantly more matches them those who wore black clothes $\left(\chi^{2}=8.52 ; p=0.004\right), 65.2 \%$ (30 victories) and 34.8\% (16 victories) respectively. Finally, table 4 displays the proportion of victories and defeats by continent of origin, and it was observed that Asian athletes won more than athletes from other continents did $\left(\chi^{2}=10.12 ; p=0.038\right), 80.4 \%$ (37 victories) and 19.6 (9 victories) respectively.

Table 4. Fight outcome distribution according to fighter's continent of origin, $\mathrm{n}(\%)$

\begin{tabular}{lcc}
\hline Continent & Defeat & Victory \\
\hline Asia* & $23(50 \%)$ & $37(80,4 \%)$ \\
America & $5(10,9 \%)$ & $3(6,5 \%)$ \\
Europe & $13(28,3 \%)$ & $5(10,9 \%)$ \\
Africa & $4(8,6 \%)$ & $1(2,2 \%)$ \\
Oceania & $1(2,2 \%)$ & $0(0 \%)$ \\
Total & $46(100 \%)$ & $46(100 \%)$ \\
\hline * Proportionally more victories than non-Asians. $\chi^{2}=10.12, p=0.038$.
\end{tabular}




\section{Discussion}

The study's aim was to analyze motor actions in female Wushu Sanda matches from the $13^{\text {th }}$ World Wushu Championships. Additionally, we investigated the existence of color bias and home advantage in this CS. As main findings, it was observed motor repertory with predominance of punches and kicks, and few throwing techniques applications, which were more used by winners. It was also observed home advantage holding up Asian athletes and color bias supporting the competitors who wore red.

Few studies investigated technical-tactical aspects in female Wushu Sanda athletes, and most of them were performed with Chinese athletes only. Besides, to the best of the authors' knowledge, this is the first study to investigate color bias and home advantage on this sport, subject studied previously in Judo (Djikstra \& Preenen, 2008; Rowe et al., 2005), Boxing, Wrestling and Taekwondo (Hill \& Barton, 2005).

It was identified that female athletes used predominantly punches and kicks (respectively $47.5 \%$ and $46.9 \%$ of all motor actions), applying few throwing techniques (5.6\% of all motor actions). These results agree with other study (Liang, 2007), who observed the same behavior on female athletes during the $3^{\text {rd }}$ Wushu Sanda World Cup (Xi'an, China, september 2006), which applied 16.2 punches (46.1\%), 14.5 kicks (41.5\%) and a restrict number of throws, $4.4(12.5 \%)$. For applying fewer throwing techniques, the athlete who applied a higher number of throws had competitive advantage, winning more matches. This may happen because throwing techniques have one of the highest score values on Wushu Sanda (2 points for a full throw, when the applier lasts standing), and if one of the competitors is thrown out of the leitai (platform were matches are held) twice, he loses the round (IWUF, 2015). This evidence was confirmed analyzing the motor actions along rounds and comparing them by match outcome, which showed that winners applied more throws on both first and second rounds.

Such as another CS (Franchini \& Takito, 2016; Julio et al., 2013), the home advantage was observed, and in this case supporting Asian athletes $\left(\chi^{2}=10.12 ; p=0.038\right)$. Previous studies pointed numerous reasons for home advantage effect, such as the travel and the crowd (Carron, Loughhead \& Bray, 2005; Franchini \& Takito, 2016; Julio et al., 2013). Since athletes most times have to travel to compete, the adaptation to the new location can be negative for visiting athletes, affecting their performance (Julio et al., 2013). The crowd is also a key factor for home advantage, since crowd's behavior tend to affect positively home athletes and negatively visitors, despite affecting referees decisions (Carron et al., 2005). Taking in consideration that Wushu is not quite popular outside Asia, athletes from other places may deal with less financial support to participate in international competition, even more knowing that, from the thirteen editions of the World Wushu Championships, only three were held outside Asia. Besides the higher number of competitors being from Asia, earlier studies had already shown the Asian countries' dominancy on this sport (Dingchuan \& Wang, 2013; Wang \& Wang, 2012). Although of dominating the modality's scene, the Asian female athletes are growing in medal numbers. Wang and Wang (2012) observed during the $10^{\text {th }}$ World Wushu Championships, held in Toronto, Canada, in 2009 (outside Asia), that Asian athletes won $35.71 \%$ of all medals, right behind Europe, who's got $39.28 \%$ of the total medals. However, Asian athletes had a higher number of gold medals (85.71\% of all golden medals), while Europe won only bronze medals. Dingchuan and Wang (2013) performed the same analysis on the $11^{\text {th }}$ World Wushu Championships, held in Ankara, Turkey, in 2011, noticing a growth on Asian's total number of medals to $46.42 \%$ while European athletes maintained their results in $39.28 \%$, and a $100 \%$ gold medal winning for Asians. On the present study, during the $13^{\text {th }}$ World Wushu Championships, held on Jakarta, Indonesia, in 2015, Asian athletes increased their medal number for $60.71 \%$ of total medals, maintaining the $100 \%$ of total gold medals, while Europe won only $17.85 \%$ of all medals.

In a pioneering manner, the main founding of this study was the existence of color bias in victories' proportion of female Wushu Sanda matches. This bias was already observed in another Olympic CS in which athletes wear blue and red, supporting the last one (Hill \& Barton, 2005). Hill and Barton (2005) suggested that these results are due to aggressiveness and dominancy associated with red color along human's evolutionary process. On the other hand, in Judo, competitors wear blue and white, and studies appointed to different directions. Rowe et al. (2005) 
claimed that judokas wearing blue win more than those wearing white due to perceptive reasons, while Djikstra and Preenen (2008) considered that this bias is due to Judo's draw method, which ends-up allocating the best fighters on the blue color to prevent best-ranked fighters' confrontation before quarterfinal.

Wushu Sanda has the particularity of using red and black, both colors associated with agressiveness and dominancy (Hill \& Barton, 2005), and nevertheless was observed yet advantage for the red clothed competitor $\left(65.2 \%\right.$ of all victories, $\left.\chi^{2}=8.52 ; \mathrm{p}=0.004\right)$. Highlights that the athletes dressing color is randomly set on the final draw, not being possible for athletes to choose what clothe and equipment's color they will wear. The color bias can offer a competitor competitive advantage just by wearing certain color, and this brakes modern sports' principle of equality, which holds that all competitors should have the same conditions for competition, and should win the one who best use the actions allowed by the modality's rules (Guttmann, 1978). Whereas there is no consensus about this bias, which can happen due to psychological reasons related to humanity evolution, enhancing athletes' performance (Hill \& Barton, 2005), or perceptive reasons by affecting visibility, offering advantage for athletes'(Rowe et al., 2005) or biasing referees' judgment (Carazo-Vargas \& Moncada-Jiménez, 2014). Since there were no differences among motor actions utilization due to the clothing color, the color may not enhance female Wushu Sanda athletes' performance. The only difference pointed between winners and losers was the higher number of applied throws for those who won. This suggests that clothing color may not affect female Wushu Sanda athletes' perception.

The most probable reason from color bias effect in Wushu Sanda female matches may be referees judgment that may be biased by the colors, offering advantage for athletes wearing red clothes. On Wushu Sanda's refereeing, the sideline judges are responsible for awarding the points for each athlete according to what they see from their place, so the red color may trigger a psychological effect in judges, biasing their perception and making them see more successful strikes in athletes who wear this color, as suggested by a previous study in Taekwondo competition (Carazo-Vargas \& Moncada-Jiménez, 2014). On Taekwondo, this referees' bias was observed by comparing matches outcomes using manual and automatic scoring systems, and the color bias effect disappeared when the automatic scoring system, which avoids referees judgment, was utilized (Carazo-Vargas \& Moncada-Jiménez, 2014).

The main limitations of this study were having the matches' analysis done by just one observer, what was minimized by testing the analysis's reproducibility, which indicated excellent levels of reproducibility for all variables (intraclass correlation coefficients from 0.75 to 0.99), and not having access to judges scored points, which should provide a new perspective on color bias investigation.

As a practical application, female Wushu Sanda athletes should expend more time training throwing techniques applications, as these motor actions are a determinant factor to victory. Few Wushu Sanda competitions are starting to change the black color for blue, in order to follow the Olympic CS tendency. Future studies should investigate the blue color impact on match outcome and the viability of implementing an automatic scoring system on Wushu Sanda in order to avoid color bias.

\section{Conclusion}

In conclusion, female international level Wushu Sanda athletes seem to prefer striking motor actions instead of grappling motor actions, and the number of successful applied throws seems to be a determinant factor to victory. It was observed home advantage supporting the Asian athletes in a championship held in Indonesia, and color bias supporting the red dressed athletes.

\section{References}

Artioli, G. G., Gualano, B., Franchini, E., Batista, R. N., Polacow, V. O., \& Lancha, A. H. (2009). Physiological, Performance, and Nutritional Profile of the Brazilian Olympic Wushu (Kung- 
$\mathrm{Fu}$ Team. Journal of Strength and Conditioning Research, 23(1), 20-25. http://dx.doi.org/10.1519/jsc.0b013e318187687a

Carazo-Vargas, P., \& Moncada-Jiménez, J. (2014). Referees bias explain red color advantage in taekwondo. Journal of Physical Education and Sport, 14(4), 485-487. https://dx.doi.org/10.7752/jpes.2014.04073

Carron, A. V., Loughhead, T. M., \& Bray, S. R. (2005). The home advantage in sports competition: Courneya and Carron's (1992) conceptual framework a decade later. Journal of Sports Sciences, 23(4), 395-407. https://dx.doi.org/10.1080/02640410400021542

Chang, B. C. (2013). On Women Sanda athletes using wrestling techniques in 2012 Shanxi Wushu Championships. Wushu Science, 10(4), 59-61.

Del Vecchio, F. B., Hirata, S., \& Franchini, E. (2011). A review of time-motion analysis and combat development in mixed martial arts matches at regional level tournaments. Perceptual and Motor Skills, 112(2), 639-648. https://dx.doi.org/10.2466/05.25.PMS.112.2.639-648

Dijkstra, P. D., \& Preenen, P. T.Y. (2008). No effect of blue on winning contests in judo. Proceedings of the Royal Society B, 275(1639), 1157-1162. https://dx.doi.org/10.1098/rspb.2007.1700

Dingchuan, W., \& Wang, J. S. (2013). From the 11th World Wushu Championships World Martial Arts. Journal of Jilin Institute of Physical Education, 29(3), 108-111.

Dreiskaemper, D., Strauss, B., Hagemann, N., \& Büsch, D. (2013). Influence of Red Jersey Color on Physical Parameters in Combat Sports. Journal of Sport \& Exercise Psychology, 35(1), 44-49.

Franchini, E., \& Del Vecchio, F. B. (2010). Judo and variability: application to technical actions during the match. In: J. F. Warnick \& W. D. Martin (Eds.), Advancements in the scientific study of combative sports (pp. 79-96). Russellville: Nova Science.

Franchini, E., \& Del Vecchio, F. B. (2011). Studies in combat sports: state of the art. Brazilian Journal of Physical Education and Sport, 25(ESP), 67-81. http://dx.doi.org/10.1590/S1807$\underline{55092011000500008}$

Franchini, E., \& Takito, M. Y. (2016). Home advantage in combat sports during the Olympic Games. Sport Sciences for Health, 12(3) 287-290. http://dx.doi.org/10.1007/s11332-016-0286-9

Guttmann, A. (1978). From ritual to record: the nature of modern sports. New York: Columbia University Press.

Hill, R. A., \& Barton, R. A. (2005). Psychology: Red enhances human performance in contests. Nature, 435(7040), 293. https://dx.doi.org/10.1038/435293a

IWUF - International Wushu Federation (2014). What is Wushu? Wushu Official Publication of International Wushu Federation 2014, 1, 11-18. Retrieved from http://www.iwuf.org/upload/2015/0316/0f564a4f0fa70f432bf17bbf278a7629a1b45871.p df

IWUF - International Wushu Federation (2015). Rules for international Wushu Sanshou Competition. 2015, 1, 11-14. Retrieved from http://www.iwuf.org/upload/2015/0206/7a33b9af9dc0fd98af72e911fa72f0d581685018.p $\underline{\mathrm{df}}$

Jiang, C. Y., Olson, M. W., \& Li, L. (2013). Determination of biomechanical differences between elite and novice San Shou female athletes. Journal of Exercice Science \& Fitness, 11(1), 25-28. http://dx.doi.org/10.1016/j.jesf.2013.03.002

Julio, U. F., Panissa, V. L. G., Miarka, B., Takito, M. Y., \& Franchini, E. (2013). Home advantage in judo: A study of the world ranking list. Journal of Sports Sciences, 31(2), 212-218. http://dx.doi.org/10.1080/02640414.2012.725855

Julio, U. F., Miarka, B., Rosa, J. P., Lima, G. H., Takito, M. Y., \& Franchini, E. (2015). Blue judogi may bias competitive performance when seeding system is not used: sex, age, and level of competition effects. Perceptual \& Motor Skills, 120(1), 28-37. https://dx.doi.org/10.2466/30.PMS.120v15x2

Kazemi, M., Perri, G., \& Soave, D. (2006). A profile of olympic taekwondo competitors. Journal of Sports Science and Medicine, 5(CSSI), 114-21.

Li, J. H., \& Qiu, R. L. (2012). The Punching Time Comparison and Analysis of Wushu's Routine Athletes ans Sanda Athletes. Wushu Science, 9(11), 61,64.

Liang, Y. D. (2007). Technical statistics of female athletes at $3^{\text {rd }}$ Wushu Sanda World Cup. Journal of Wuhan Institute of Physical Education, 41(3), 89-96. 
Liu, C. Z., \& Zhang, Y. (2007). Application of Blood Lactic Acid in Physical Stamina Training and Effects Evaluation of Sanda. Journal of Chengdu Sport University, 33(2), 84-85.

Miarka, B., Marques, J. B., \& Franchini, E. (2011). Reinterpreting the history of women's judo in Japan. International Journal of the History of Sport, 28(7), 1016-1029. http://dx.doi.org/10.1080/09523367.2011.563633

Miarka, B., Branco, B. H. M., Del Vecchio, F. B., Camey, S., \& Franchini, E. (2015). Development and validation of a time-motion judo combat model based on the Markovian Processes. International Journal of Performance Analysis in Sport, 15(1), 315-131.

Pasque, C. B. (2009). Women in Combat Sports. In: R. Kordi, N. Maffull, R. R. Wroble, \& W. A. Wallace (Eds.), Combat Sports Medicine (pp. 135-150). London: Springer-Verlag.

Rowe, C., Harris, J. M., \& Roberts, S. C. (2005). Sporting contests: seeing red? Putting sportwear in context. Nature, 437(7063), E10-E11. https://dx.doi.org/10.1038/nature04306

Silva, J. J. R., Del Vecchio, F. B., Picanço, L. M., Takito, M. Y., \& Franchini, E. (2011). Time-Motion analysis in Muay-Thai and Kick Boxing amateur matches. Journal of Human Sport \& Exercise, 6(3), 490-496. http://dx.doi.org/10.4100/jhse.2011.63.02

Wang, Z., \& Wang, W. (2012). Development Pattern of Sanda from 10th World Wushu Championships. Wushu Science, 9(3), 11-12.

Yin, H. L. (2010). An Analysis of Technique and tactics Characteristics of Men's Sanshou Final in the 11th National Game. Journal of Beijing Sport University, 33(6), 139-142.

Zeng, Y. J., Zhang, L., \& Zhou, M. (2009). On Wushu Sanshou and Wushu Sanda. Journal of Wuhan Institute of Physical Education, 43(1), 69-73.

\section{Author's biographical data}

Breno Berny Vasconcelos (Brazil), Physical Education student in ESEF/UFPel. Technical director of the Rio Grande do Sul state Wushu Taolu team (Brazil). Athlete of the Brazilian Wushu Taolu National Team (20142015). Member of the group of studies and research in sports training and human performance (GEPETED) in ESEF/UFPel. Black belt in Wushu. E-mail: brenobvasc@gmail.com

Fabrício Boscolo Del Vecchio (Brazil), PHD in Physical Education in FEF/UNICAMP, PHD advisor in ESEF/UFPel. Leader of the group of studies and research in sports training and human performance (GEPETED) in ESEF/UFPel. Black belt 2º dan in Judo. E-mail: fabricio boscolo@uol.com.br 